\title{
RANCANG BANGUN SISTEM MONITORING DAN CONTROLLING PENERANGAN JALAN UMUM BERBASIS IOT DAN ANDROID
}

\author{
(Design of Monitoring and Controlling for Public Street Lighting Based in IoT \\ and Android)
}

\author{
Rijalul Imam, I Gede Putu Wirarama Wedashwara W*, Fitri Bimantoro \\ Program Studi Teknik Informatika, Fakultas Teknik, Universitas Mataram \\ JI. Majapahit 62, Mataram, Lombok NTB, INDONESIA \\ Email: rijall.as196@gmail.com, [wirarama,bimo]@unram.ac.id
}

\begin{abstract}
Public street lighting is an element or component that must be present in every road, functioning as street lighting at night for the safety of motorists. Most of public street lighting is lit at night through morning continuously without a system of monitoring and control, which is consuming electricity. Therefore, in this study a prototype system was designed to monitor and control public street lighting based on IoT and Android. It uses wemos D1 as a microcontroller and the relay module as a switch, as well as the LDR sensors for light intensity retrieving. The streetlight was normally light only on at night when it was off during the day. Monitoring research and illegal street lighting will not only be done on and off lights but also be switched on and off lights automatically on time. Officials can also monitor oring light conditions through an android app.
\end{abstract}

Keywords: Internet of Things, Monitoring, Public Street Lighting, Street Lighting, SensorLDR.

*Penulis Korespondensi

\section{Pendahuluan}

Lampu Penerangan Jalan Umum (LPJU) merupakan infrasruktur bagi pengendara roda dua, tiga dan lebih. Hampir disetiap jalan raya, dipasang lampu penerangan jalan yang berfungsi untuk menerangi area jalan yang dilalui oleh pengendara, fungsi lain dari LPJU adalah keamanan dan keindahan. Fungsi keamanan, bertujuan memperluas jarak pandang pengendara untuk melewati jalan pada malam hari, pengendara juga membutuhkan penerangan dengan cahaya tertentu untuk mengurangi resiko kecelakan dan tindak kriminal. Sedangkan fungsi keindahan tidak lepas dipengaruhi oleh design dan tata letak lampu untuk memperindah jalan sekaligus wajah kota pada malam hari [1].

Pada saat ini penggunaan lampu jalan umum menggunakan lampu konvensional untuk penghematan energi [2]. Namun karena banyaknya LPJU yang terpasang dan lampu jalan umum akan menyala sepanjang malam dengan kecerahan maksimal sehingga masih menyebabkan pemborosan [3]. Biasanya keadan jalan pada tengah malam mulai jarang pengendara untuk melintasi jalan. Dalam melakukan pendataan kerusakan lampu jalan umum (tidak menyala), saat ini masih banyak petugas yang memonitoring lampu jalan umum menggunakan sistem manual [4]. Pemantauan dan pengendalian lampu, masih dilakukan dengan cara mendatangi tempat/lokasi dimana lampu penerangan jalan umum dipasang, petugas secara berkala memeriksa satu persatu kondisi lampu jalan umum [3]. Pengontrolan secara manual memiliki kekurangan karena membutuhkan waktu untuk mengetahui kondisi dari lampu oleh petugas.

Berdasarkan paparan yang telah dijelaskan maka akan dibangun sistem monitoring dan controlling penerangan lampu jalan umum berbasis IoT dan android untuk memudahkan petugas yang mengontrol lampu penerangan jalan umum dari jarak jauh, petugas dapat mengurangi tegangan aliran listrik yang dialirkan ke lampu sehingga tingkat terangnya lampu dapat dikontrol, lampu yang biasanya menyala $100 \%$ atau maksimal pada tengah malam dapat diturunkan menjadi 66\% dan 33\% tanpa mengganggu aktivitas kenyamanan pengguna jalan [2]. Petugas juga dapat men-setting lampu berdasarkan waktu.

\section{TinJaUAN PUSTAKa}

Penelitian tentang rancang bangun alat monitoring kerusakan lampu penerangan jalan umum berbasis mikrokontroler dibuat dengan menggunakan sensor tegangan, sensor arus dan sensor cahaya dengan notifikasi sms sebagai media untuk memberikan informasi mengenai keadaan lampu jalan umum. Alat ini beroprasi secara otomatis dalam memberikan notifikasi SMS dan dapat juga dioperasikan pada saat diperlukan untuk pengecekan keadaan lampu jalan umum dengan cara mengirimkan SMS pada alat dengan kode atau pesan "CEK LPJU" maka alat akan memberikan timbal balik berupa keadaan lampu sesuai dengan kode yang di-input-kan 
Perintah SMS "CEK LPJU” akan dikirim ke modul GSM kemudian akan memberikan perintah pada mikrokontroler untuk mengolah nilai yang dibaca sensor [1].

Penelitian tentang perancangan kontrol dan memonitoring lampu jalan umum dengan menggunakan panel surya untuk mendapatkan energi dan menggunakan fuzzy logic sebagai pengambilan keputusan, pada penelitian ini juga menggunakan sensor LDR untuk mendapatkan intensitas cahaya selain itu juga pada penelitian ini digunakan sensor photodiode sebagai counter kendaraan. Panel surya digunakan untuk mendapatkan energi untuk menyalakanlampu kemudian disimpan pada charger baterai. Untuk photodiode sensor digunakan untuk mengetahui jumlah dari kendaraan pada penelitian ini diperoleh 0-80 mobil [3].

Penelitian tentang controlling detection of public street light using wireless connection bertujuan untuk memberikan kenyamanan bagi pengguna jalan. Penelitian menggunakan sensor LDR dan Dimmer sebagai mikrokontroler dengan media kontrol dan menerima informasi dari kondisi lampu jalan umum melalui web browser. Pada penelitian ini menggunakan 2 rangkaian atau lampu-1. Sensor LDR-1 berfungsi untuk mendeteksi intensitas cahaya pada lingkungan sekitar, diperoleh data ADC dengan nilai intensitas yang didapatkan pada rangkaian 1 yaitu dari 1-10.000, untuk mendapatkan persamaan. Kemudian dilakukan pengujian kembali jika data yang diperoleh dengan tingkat error $<3.23 \%$ maka dinyatakan berhasil. Begitu juga pada rangkaian 2 atau lampu-2 [4].

Penelitian tentang pembuatan sistem pengontrolan intensitas cahaya lampu menggunakan rasberry pi bertujuan untuk mngontrol lampu ruangan dengan menggunakan mobile dengan menggunakan pendekatan User-Centered Design (UDC). Sistem yang dibangun ini memiliki fungsional yang tidak terbatas dalam menyalakan dan mematikan lampu, tetapi dapat mengatur tingkat intensitas cahaya dari beberapa lampu yang tepasang dalam ruangan dengan menggunakan menu dimmer light pada android, dimmer light memiliki pilihan dari angka 04 dimana semakin tinggi angka yang dipilih maka nyala lampu akan semakin terang [6].

Penelitian tentang kontrol lampu jalan untuk menghemat energi. Penelitian ini memanfaatkan sensor cahaya dan menggunakan sensor kendaraan serta menggunakan lampu LED sebagai lampu hemat energi. Sensor cahaya digunakan untuk menyalakan dan mematikan lampu pada saat pagi dan sore hari, sedangkan sensor kendaraan untuk menyalakan lampu apabila ada kendaraan yang lewat. Penelitian ini juga dibuat menggunakan rangkaian dimmer yang digunakan untuk membuat lampu LED redup dan terang. Daya yang dapat di hemat karena menggunakan lapu LED yaitu sebesar $68,4 \%$ [7].

\section{Metode Perancangan}

\subsection{Perancangan Arsitektur Sistem}

Rancangan sistem yang dibuat merupakan sistem monitoring dan controlling penerangan lampu jalan umum berbasis IoT dan android. Terdapat sembilan komponen penting yang terlibat dalam perancangan alat diantaranya Dimmer, dimmer, Relay, ADS1115, sensor cahaya LDR, lampu led, handphone/android, server dan koneksi internet.

Dimmer merupakan sebagai microcontroller sebagai media untuk menghubungkan semua komponen dari perangkat keras. Dimmer merupakan sebagai alat untuk mengatur tingkat ketegangan listrik guna untuk mengatur terangnya cahaya lampu. Relay merupakan alat yang digunakan sebagai saklar untuk menyalakan dan meredupkan lampu. sensor LDR sebagai alat untuk mengambil intensitas cahaya lampu yang akan terpasang pada setiap masing-masing lampu yang dirangkaikan dengan modul ADS115 yang digunakan sebagai pembaca nilai alanog yang didapatkan dari sensor LDR. Karena sistem yang dibuat merupakan pengontrolan dari jarak jauh maka tentu dibutuhkan koneksi internet sebagai penghubung dalam hal pengiriman dan penerimaan data dari alat yang sudah dibangun dengan sistem berbasis android dengan melalui server. Sedangkan untuk Android digunakan sebagai media untuk me-monitoring dan controlling lampu dari kejauhan. Untuk lebih jelasnya bisa dilihat pada Gambar 1.

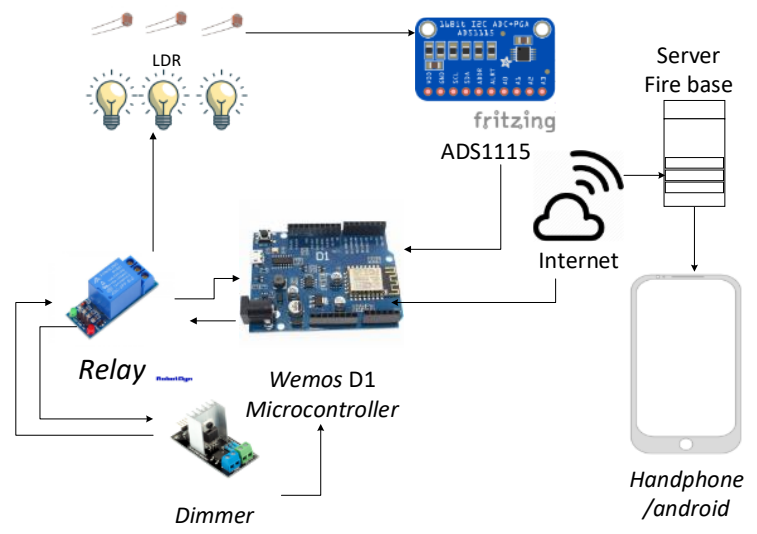

Gambar 1. Arsitektur sistem monitoring dan controlling penerangan lampu jalan

\subsubsection{Perancangan Perangkat Keras}

Pada tahap ini akan dilakukan perancangan perangkat keras untuk sistem monitoring dan controlling lampu jalan dengan android. 


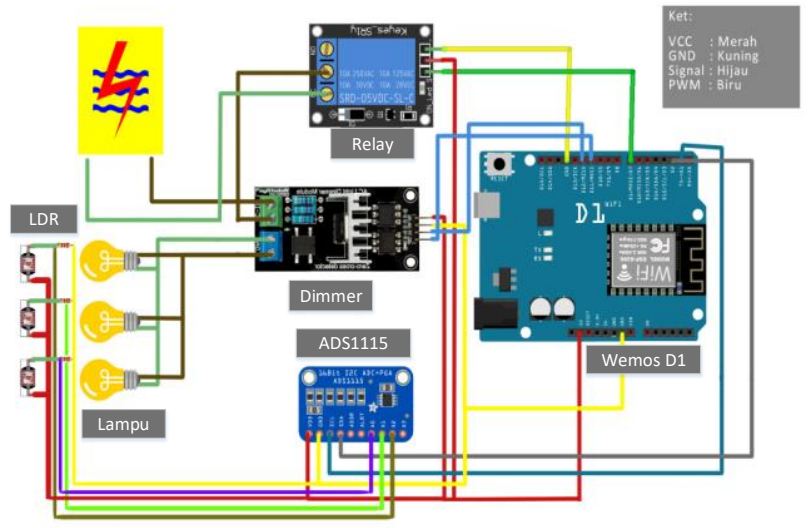

Gambar 2. Rancangan perangkas keras sistem monitoring dan controlling penerangan lampu jalan

Pada Gambar 2. merupakan rancangan perangkat yang akan dibangun pada penelitian ini, dipasang rangkaian sensor cahaya LDR untuk menangkap intensitas cahaya dari lampu, dimmer yang mengatur input-an tegangan listrik dari PLN, dan Relay yang akan dihubung dengan Dimmer sebagai mikrokontroler. Untuk lebih jelasnya sebagai berikut:

1. Module Dimmer digunakan untuk mengontrol tingkat terangnya cahaya lampu dan daya lampu. Dimmer yang digunakan memiliki tegangan 220 Volt. Dimmer yang digunakan memiliki 4 pin/kaki, ACC, GND, PWM dan Z-C. Pin ACC dihubungkan dengan pin power pada mikrokontroler (Dimmer), kemudian pin GND dihubungkan dengan pin GND Dimmerdan pin PWM dengan Z-C dihubungkan dengan pin PWM D12 dan D11 pada Dimmer. Lampu yang dirangkaikan dengan dimmer dirangkai dengan paralel artinya dimmer akan meredupkan lampu jalan secara bersamaan.

2. Relay yaitu digunakan sebagai saklar untuk memutuskan arus beban (ON/OF). Pada Relay terdapat 3 kaki/pin, yaitu GND, ACC (Aliran Listrik) dan pin input signal yang dihubungkan ke mikrokontroler. Pin GND dihubungkan ke pin GND Dimmer, kemudian pin ACC dibuhubungkan ke pin $5 \mathrm{~V}$ pada Dimmer sebagai tegangan listrik.

3. Lampu akan dipasangkan secara paralel yang tersambung dengan dimmer yang nantinya akan meredupkan lampu secara bersamaan, dalam menghidupkan, meredupkan dan mematikan lampu, lampu akan dihubungkan ke Relay.

4. Sensor LDR, dipasang pada masing-masing setiap lampu yang akan mengambil inensitas cahaya dari nyala lampu. Sensor LDR ini juga nantinya akan memberikan informasi mengenai kerusakan pada lampu, kerusakan artinya jika salah satu lampu mati tidak pada waktunya.

5. ADS1115 digunakan sabagai pembaca analog pada sensor LDR. ADS memiliki $10 \mathrm{kaki} / \mathrm{pin}$. Pin GND tehubung dengan GND pada Dimmer, VDD dihubungkan dengan tegangan pada Dimmer, kemudian kaki SCL dan SDA pada ADS1115 dihubungkan dengan D1 dan D2 pada Dimmer, untuk dihubungkan ke LDR digunakan A0 dan A1 pada pin ADS1115.

\subsubsection{Rancangan Perangkat Lunak}

\section{Rancangan usecase}

Berikut ini merupakan rancangan pembuatan use case pada sistem monitoring dan kontrol penerangan jalan umum berbasis IoT dan android dapat dilihat pada gambar 3.

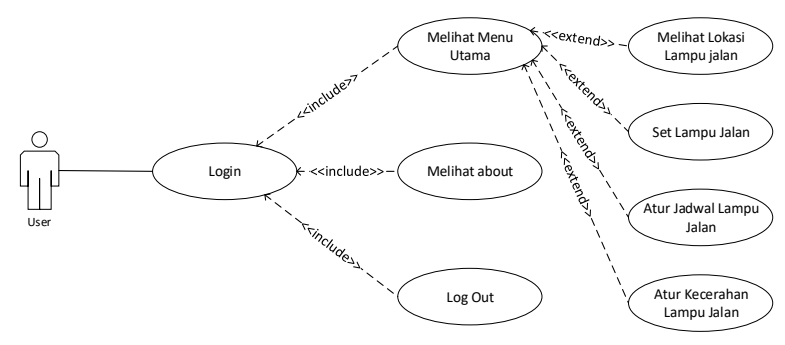

Gambar 3. Rancangan usecase diagram

Usecase diagram dibangun dimana memiliki satu user yang menjadi pengelola lampu jalan. Sistem yang dibangun ini diharapkan dapat digunakan di dinas perumahan dan permukiman. Pada sistem yang dibangun pengelola lampu jalan dapat melakukan beberapa aksi yaitu melihat menu utama, melihat about, melihat lokasi lampu jalan, set lampu jalan, mengatur jadwal untuk menyalakan lampu jalan, mengatur kecerahan lampu jalan dan terakhir pengelola dapat log out sari sistem.

\section{Alur data}

Rancangan alur dari sistem monitoring dan kontrol lampu jalan umum. Client pada android akan mengirimkan data (HTTP request) pada server kemudian akan diteruskan ke mikrokontroler dimmer ebagai penghubung ke komponen lain, dimmer akan meredupkan lampu melalui Relay. Sensor LDR memberikan output salah satu atau semua lampu mati dengan tiba-tiba. Setelah di proses pada alat maka akan dikembalikan pada server dan diteruskan ke android dengan response nyala, redup dan mati pada lampu. Lampu merupakan sebagai hasil akhir atau output. Dimmer akan meredupkan lampu melalui Relay. Relay akan memberikan output pada lampu berupa nyala dan tidaknya. Untuk lebih jelasnya dapat dilihat pada Gambar 4.

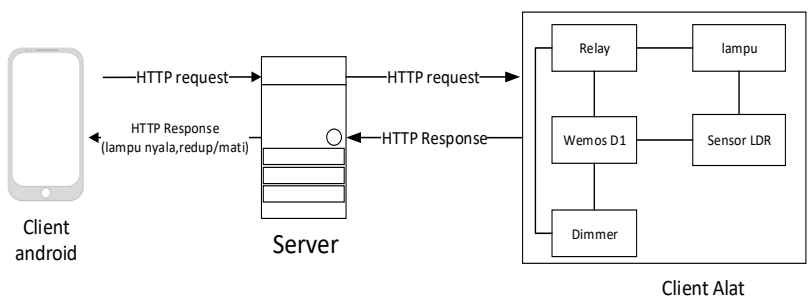

Gambar 4. Rancangan alur data dari system 


\section{Flowchart sistem}

Dilakukan perancangan flowchart untuk sistem monitoring dan kontrol lampu jalan berbasis loT dan android, dimana dengan sistem ini nanti petugas yang menangani lampu jalan dapat me-monitoring lampu dari kejauhan.

a. Flowchart alur sistem peredupan lampu jalan

Berikut ini merupakan rancangan dari alur kerja untuk peredupan lampu jalan. Dalam memanajemen pengaturan lampu melalui android dengan penjadwalan. Pada pukul 18.00 maka lampu akan menyala, kemudian pada pukul $18.00 \mathrm{~s} / \mathrm{d} 19.30$ dan pada pukul $01.30 \mathrm{~s} / \mathrm{d} 05.30$ Wita, maka Relay akan menyala (ON) kemudian akan melewati dimmer dan lampu akan redup. Jika tidak maka Relay OFF dan lampu akan mati. Jika tingkat keredupan lampu kurang dari tingkat redup semestinya, maka lampu dikatakan bermasalah dan dapat di monitoring pada fitur monitoring lampu pada android. Untuk lebih jelasnya dapat dilihat dari Gambar 5.

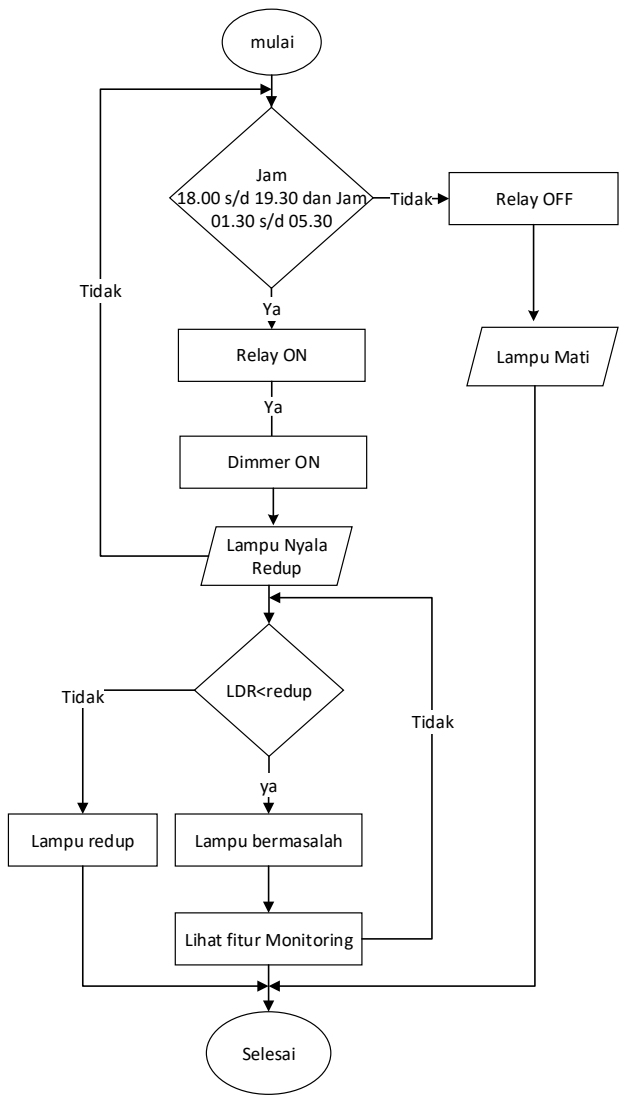

Gambar 5. Flowchart alur sistem pada peredupan lampu jalan

\section{b. Flowchart alur sistem penerangan lampu jalan}

Berikut ini merupakan perancangan pembuatan flowchart alur sistem dengan menggunakan waktu pada sistem monitoring dan kontrol penerangan jalan umum berbasis loT dan android.

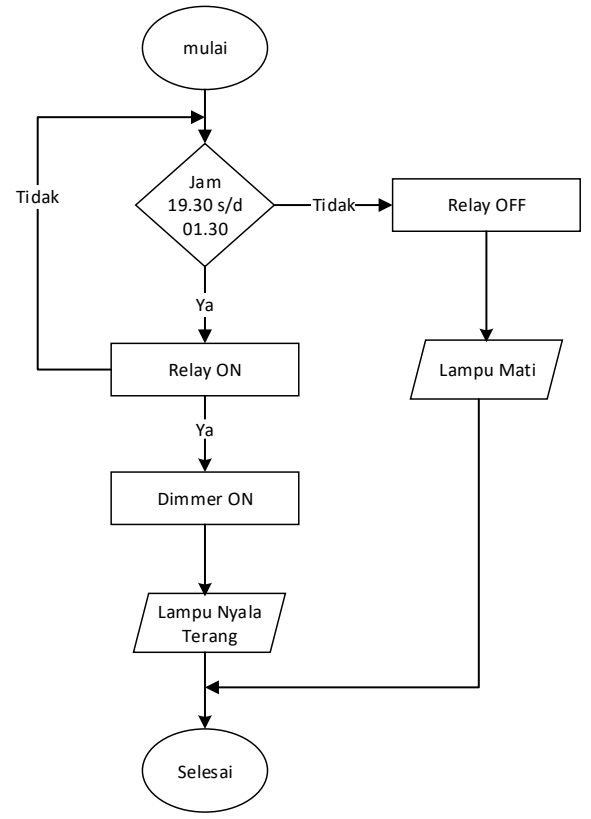

Gambar 6. Flowchart alur sistem pada penerangan lampu jalan

Gambar 6 Merupakan alur kerja dari sistem dalam memanajemen pengaturan lampu melalui android dalam penjadwalan. Pada pukul 19.30 s/d 01.30. Wita, maka Relay akan menyala (ON) dan dimmer (ON) maka akan menyalakan lampu menjadi Terang. Jika tidak, maka Relay (OFF) kemudian lampu mati.

\subsubsection{Penggunaan Waktu/Logging Time Series}

Sistem monitoring dan controlling penerangan lampu jalan memiliki salah satu fitur yaitu otomatis dari segi mengatur waktu (jam). Waktu yang dimaksudkan disini yaitu pengguna sistem dapat mengatur waktu dalam hal menyalakan, meredupkan dan mematikan lampu jalan melalui android. Untuk mendapatkan waktu yang real time, maka diambil dari keterhubungan dengan internet. Dimmerakan terkoneksi dengan internet sehingga data input-an waktu yang digunakan untuk menjalankan sistem didapatkan dari internet untuk mensinkronisasi dengan waktu setempat. Lampu akan mulai menyala pada pukul 18:00 dan akan mati pada pukul 05.30. Alur penggunaan waktu dapat dilihat dari flowchart Gambar 6.

\section{Hasil Dan Pembahasan}

Berikut adalah hasil dari penelitian yang telah dilakukan mengenai Rancang Bangun Sistem Monitoring dan Controlling Penerangan Jalan Umum Berbasis IoT dan Android. Meliputi Validasi dan kalibrasi sistem, implementasi arsitektur sistem, hasil dari pengujian sistem serta tahap analisa pada sistem yang dibuat.

\subsection{Realisasi Sistem}

Pada tahap ini akan dilakukan implementasi dari sistem yang akan dibagi dalam tiga tahap yaitu implementasi mengenai penyusunan perangkat keras, 
implementasi sistem kontrol dan implementasi mengenai penyusunan perangkat lunak berbasis android.

\subsubsection{Realisasi Penyusunan Perangkat Keras (Hardware)}

\section{Menggunakan Modul Dimmer}

Pada awalnya penelitian yang akan dibuat adalah Monitoring dan Controlling Penerangan Jalan Umum Berbasis IoT dan Android yang dapat mengatur tingkat terangnya lampu jalan, alat yang digunakan untuk mengontrol tingkat terangnya cahaya adalah modul dimmer.

Pada saat melakukan penelitian berlangsung alat yang dirancang berjalan sesuai dengan yang telah dirancang dalam mengatur redup terangnya cahaya lampu. kemudian pada saat dilakukan penelitian kembali terjadi suatu hal yang tidak terduga, modul dimmer yang digunakan sebagai mengatur tingkat terangnya cahaya mengalami kebakaran pada resistor. Sehingga alat yang digunakan tidak dapat digunakan kembali. Sehingga penelitian pada saat itu terhenti.

Dalam hal ini yang menjadi penyebab terjadinya kebakaran pada modul dimmer dikarenakan loncatan rentang tegangan listrik yang dialami terlalu jauh, seperti pada saat melakukan peredupan $30 \%$ maka tegangan listrik rendah, kemudian dinaikkan menjadi $100 \%$. Hal inilah yang menjadi penyebab terjadinya kebakaran pada modul dimmer. Solusi untuk menggunakan modul dimmer adalah dengan memberikan Source code perulangan dalam pada pengaturan tingkat terang redupnya lampu. Seperti pada soure code dibawah ini:

\section{dimmer.setPower(outVal); // setPower(0-100\%);}

for(int $\mathrm{i}=1 ; \mathrm{i}<=$ outVal; $\mathrm{i}++$ ) \{

dimmer.setPower(i); // setPower(0-100\%);

Serial.println(i);

delay (200); \}

Gambar 7. Pengaturan Tegangan pada Dimmer

Berikut adalah rancangan setelah dimmer tidak digunakan:

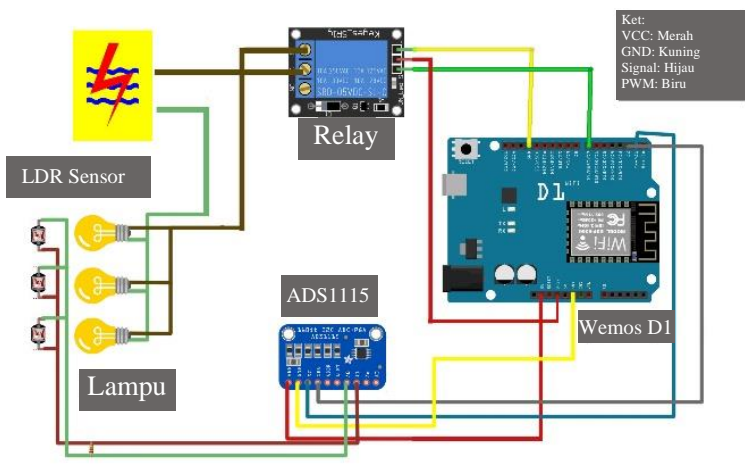

Gambar 8. Perancangan Tidak Menggunakan Modul Dimmer

\section{Menggunakan Relay}

Berikut ini merupakan realisasi perancangan perangkat keras pada penelitian Monitoring dan Controlling Penerangan Jalan Umum Berbasis IoT dan Android. Sistem yang akan dibuat nantinya dapat membantu untuk memudahkan petugas dalam melaksanakan tugas seperti mengontrol lampu dari jarak kejauhan, baik itu menyalakan lampu dan mematikan lampu jalan serta petugas juga dapat mengetahui keadaan lampu pada saat mati. Berikut ini merupakan implementasi alat yang dirancang.

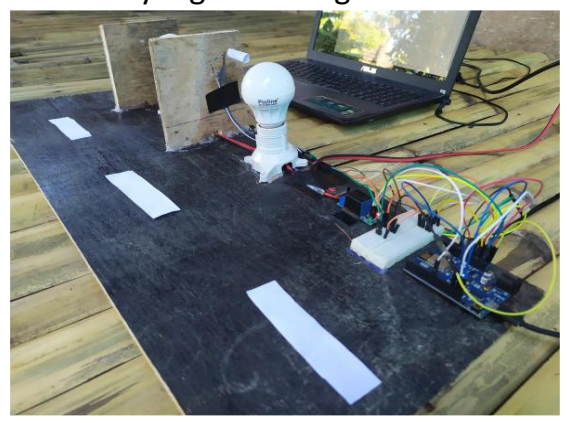

Gambar 9. Relasi Perangkat Keras Secara Keseluruhan

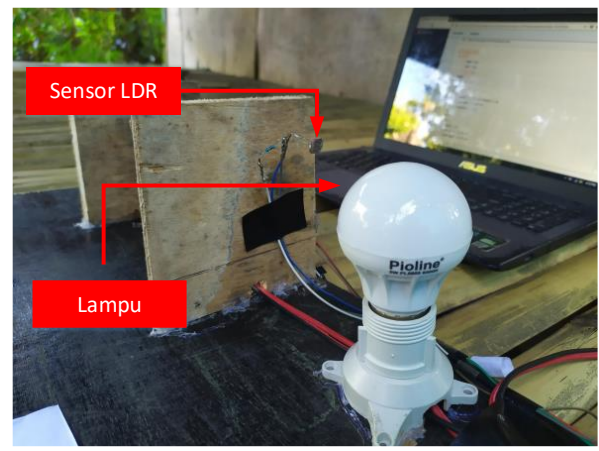

Gambar 10. Relasi Perangkat Keras Lampu dan Sensor LDR

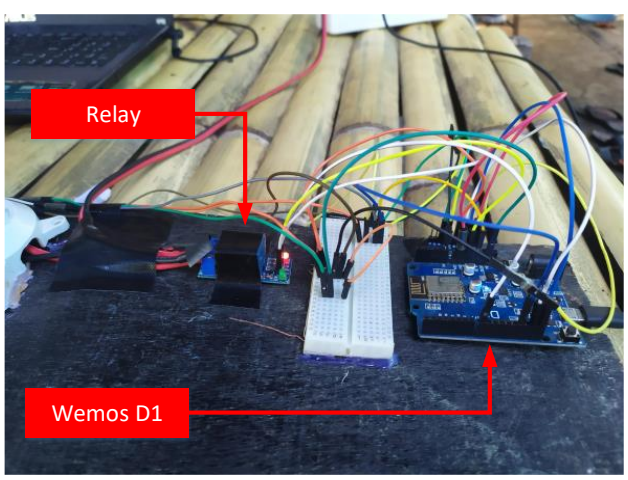

Gambar 11. Perangkat Keras dari Keseluruhan

Realisasi pada Gambar 9, 10, 11 memiliki 4 komponen utama dalam membuat alat ini antara lain, Wemos D1, Relay, sensor LDR dan ADS1115. Wemos D1 digunakan sebagai mikrokontroler untuk mengontrol, memonitoring lampu maupun sensor cahaya (LDR), yang dimana wemos D1 ini sudah memiliki modul ESP8266 sebagai penghubung ke internet. Relay digunkan sebagai saklar untuk 
menyalakan dan mematikan lampu, yang dimana Relay akan terhubung dengan arus listrik bertegangan $220 \mathrm{~V}$ atau listrik PLN. Sensor Light Dependent Resistor (LDR) digunakan seabagai memonitoring dari lampu, jika salah satu lampu mengalami gangguan (mati) maka akan memberikan notofikasi pada system yang dibuat. Modul ADS1115 digunakan sebagai tambahan dari pin analog pada mikrokontroler wemos D1 yang akan dihubungkan pada sensor LDR.

\subsubsection{Realisasi Pembangunan pengontrolan}

Realisasi pengembangan pembangunan tahap pengontrolan ini, dibuat menggunakan bahasa pemrograman $\mathrm{C}$ dengan menggunakan aplikasi Arduino IDE.

\#include <ESP8266WiFi.h>

\#include "FirebaseESP8266.h"

\#include <Adafruit_ADS1015.h>

Gambar 12. Code Library

Script pada Gambar 12 merupakan library yang digunakan, yang memiliki fungsi masing masing-masing. "\#include "FirebaseESP8266.h" yang digukan untuk menghubungkan firebase dengan mikrokontroler "\#include <ESP8266WiFi.h" merupakan library yang digunakan untk modul wifi ESP8266 pada wemos D1, dan "\#include "Adafruit_ADS1015.h" merupakan library yang digunakan pada modul ADS1115.

\#define FIREBASE_HOST "https://penerangan-2e2f3.Firebaseio.com/"
\#define FIREBASE_AUTH
"V2fhcNs6IhRhAtMVqKbksJMEXXHeZnNInXAdGNyS"
\#define WIFI_SSID "the cac"
\#define WIFI_PASSWORD "rijal196"
\#define Relay D8
Adafruit_ADS1115 ads(0x49);
FirebaseData FirebaseData;
const int IdrPin = A0;

Gambar 13. Code Koneksi ke Firebase

Pada source code "\#define FIREBASE_HOST" dan "\#define FIREBASE_AUTH" di Gambar.13 digunakan untuk mendeklarasikan alamat dari Firebase yang digunakan sebagai tempat untuk menampung data yang digunakan. "WIFI_SSID" digunakan untuk mendeklarasikan nama jaringan yang digunakan "WIFI_PASSWORD" digunakan untuk menampung password jaringan wifi yang digunakan dan untuk "\#define Relay D8" merupakan berfungsi untuk mendeklarasikan pin yang digunakan dari Relay. "Adafruit_ADS1115 ads(0x49);" untuk menjalankan modul ADS1115, di-se t"(0x49);" karena pin ADDR pada ADS1115 dihubungkan dengan VCC/VDD. "const int IdrPin = AO;" merupakan untuk mendeklarasikan pin yang digunakan oleh sensor LDR pada wiemos D1.

Source code "void setup()" pada Gambar.14 memiliki fungsi untuk mengatur modul-modul yang sesuai dengan library yang telah digunakan sebelumnya, fungsi lain juga untuk mengatur proses koneksi dan mendeklarasikan ssid, password. Fungsi "pinMode(relay, OUTPUT); ", "digitalWrite(relay, LOW);" membaca nilai pin relay yang telah dideklarasikan sebelumnya. "ads.begin(); merupakan bawaan dari library ADS1115.

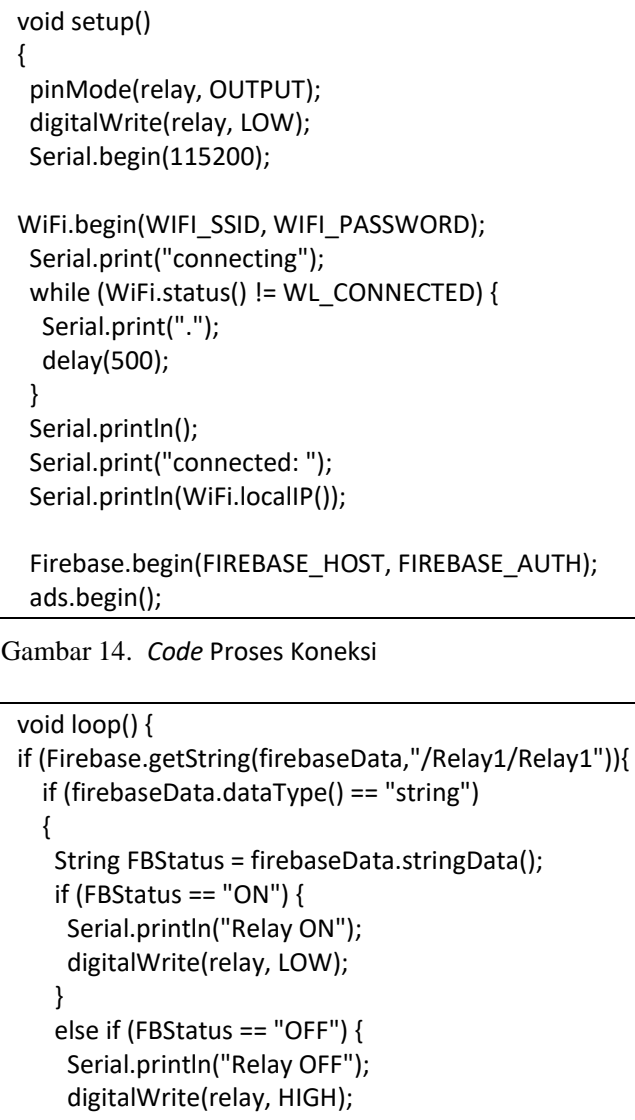

Gambar 14. Code Proses Koneksi

Gambar 15. Code Mengambil Nilai Relay pada Firebase

Gambar.15 Source code "void loop()" merupakan fungsi untuk melakukan proses perulangan untuk memabaca nilai lampu yang ada pada Firebase "/Relay1/Relay1" yang sudah terkoneksi dengan mikrokontroler. Jika nilai yang dibaca "ON" maka lampu akan menyala begitu juga dengan sebaliknya jika nilai yang dibaca "OFF" maka lampu akan mati.

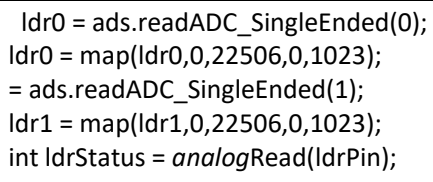

Serial.print("LDRO: ");Serial.printIn(IdrStatus);

Serial.print("LDR1: "); Serial.println(IdrO);

Serial.print("LDR2: "); Serial.println(Idr1); delay(1000);

Gambar 16. Code Pembacaan Intensitas Cahaya 
Source code pada Gambar. 16 digunakan untuk membaca intensitas cahaya dari lampu dengan sensor LDR, terdapat 3 pin analog yang dihubungkan dengan sensor LDR. Digunakan 2 pin analog dihubungkan dengan ADS1115 "Idro", "Idr1" dan 1 pada wemos D1 "int IdrStatus = analogRead(IdrPin);".

Firebase.setInt(firebaseData,"/LDR/LDR0", (IdrStatus));

Firebase.setInt(firebaseData,"/LDR/LDR1", (Idr0));

Firebase.setInt(firebaseData,"/LDR/LDR2", (Idr1)); delay(5000);

Gambar 17. Code Set Nilai Intensitas Cahaya ke Firebase

Source code pada Gambar 17 digunakan untuk menyimpan nilai intensitas cahaya dari lampu dengan sensor LDR ke firebase. "Firebase.setInt(firebaseData,"/LDR/LDRO", (IdrStatus));" digunakan untuk membuat dan menampung nilai pada tabel database firebase dengan delay untuk menyimpan adalah 5 detik.

\subsection{Realisasi Pembangunan Database (Firebase)}

Pada penelitian ini yang digunakan sebagai tempat menampung data adalah Firebase dimana Firebase dapat diakses dimanapun asalkan memiliki koneksi internet karena yang dibuat adalah aplikasi android tentunya untuk dapat memudahkan pengaksesan oleh petugas diluar kantor. Berikut ini realisasi dari data pada Firebase yang telah dibuat.

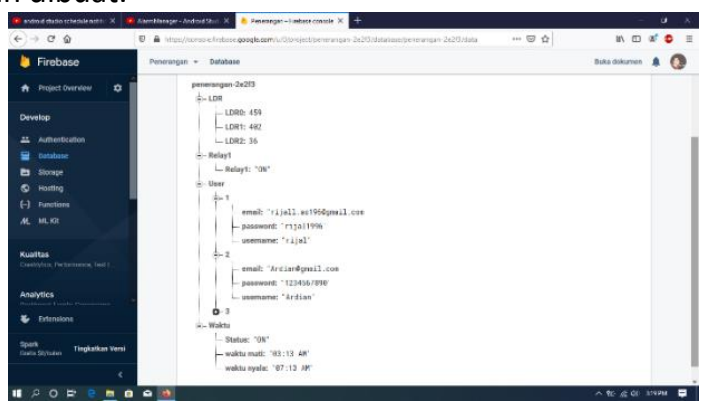

Gambar 18. Realisasi Firebase sistem monitoring dan kontroling lampu jalan umum

Pada database penerangan pada Gambar 18 memiliki tiga tabel untuk menamping data, Relay1 sebagai tempat untuk menampung status nilai dari lampu, User penampungan data untuk login pada aplikasi dan Waktu untuk menampung nilai status dari lampu pada saat dilakukan penjadwalan untuk menyalakan dan mematikan lampu oleh petugas.

\subsection{Realisasi Pereangkat Lunak}

Berikut ini adalah tampilan dari siste yang telah dibuat berdasarkan perancangan sebelumnya.

\subsubsection{Halaman Login dan Buat Akun}
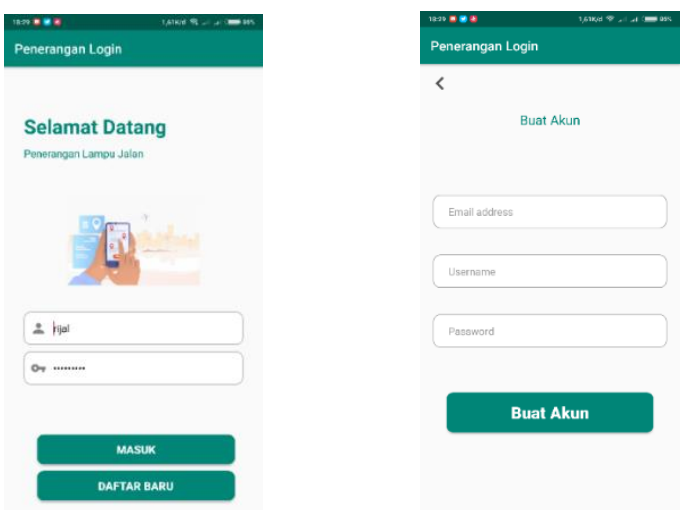

Gambar 19. Halaman Login dan Buat Akun

Gambar 19 merupakan realisasi dari interface login sistem monitoring dan controlling penerangan lampu jalan berbasis IoT dan Androit, halaman ini merupakan pertama kali akan tampil setelah aplikasi dibuka dimana terdapat dua Formusername dan password. Jika petugas sudah memiliki akun maka dapat langsung login tetapi jika tidak memiliki akun maka dapat membuat akun baru dengan memilih fitur daftar baru. Pada Gambar 4.7 merupakan halaman untuk membuat akun petugas dapat membuat akun dengan mengisi Form yang telah disediakan, terdapat tiga Form buat akun yaitu Form Email address, Username dan Password.

\subsubsection{Halaman Menu Utama}

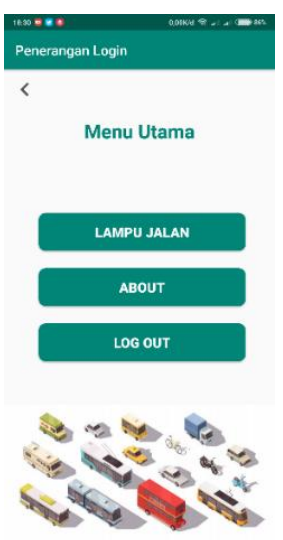

Gambar 20. Halaman Menu Utama

Pada Gambar 4.20 merupakan halaman menu utama dari interface login sistem monitoring dan controlling penerangan lampu jalan berbasis IoT dan Androit, menu utama dapat diakses ketika sudah login terlebih dahulu. 


\subsubsection{Halaman Jalan dan Setting}

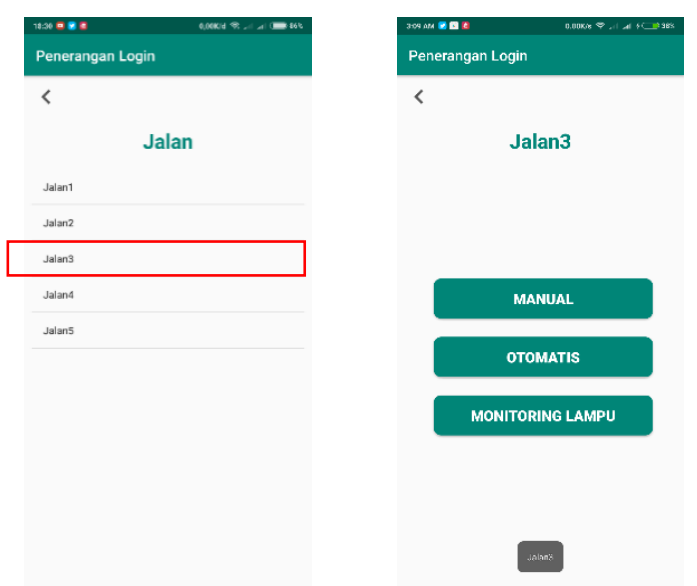

Gambar 21. Halaman Jalan dan Setting

Terlihat pada Gambar 21 terdapat dua interface sistem yaitu interface jalan dan interface setting. Interface jalan dapat diakses setelah memilih fitur lampu jalan pada Formsebelumnya, terdapat pilihan jalan untuk di control dan monitoring. Jika petugas memilih jalan3 maka akan langsung masuk ke interface setting disana dapat dua buah fitur petugas dapat memilih fitur manual ataupun otomatis

\subsubsection{Halaman Manual dan Otomatis}
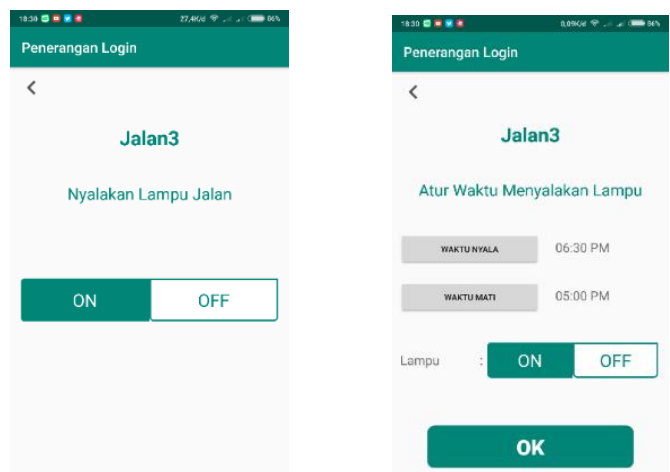

Gambar 22. Halaman Manual dan Otomatis

Gamabar 22 merupakan halaman untuk melakukan proses menyalakan dan mematikan lampu dengan manual atau otomatis, manual disini petugas hanya dapat menyalakan dan mematikan lampu dari jarak jauh menggunakan aplikasi android, terlihat pada halaman manual hanya memiliki dua fitur yaitu ON dan OFF. Sedangkan untuk otomatis petugas dapat menyalakan dan mematikan lampu dengan mengatur waktu. Petugas dapat meng-input-kan rentan waktu dalam menyalakan maupun mematikan lampu dengan memilih fitur yang telah disediakan.

\subsubsection{Halaman Memilih Waktu}

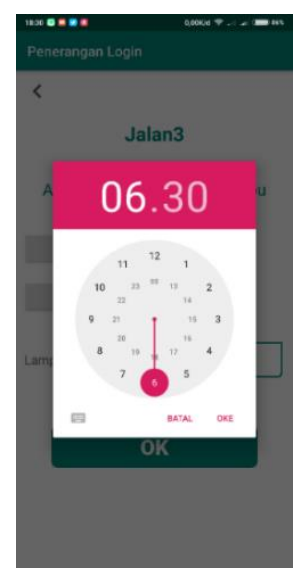

Gambar 23. Halaman Memilih Waktu

Gambar 23 merupakan interface untuk memilih waktu pada sistem monitoring dan controlling penerangan lampu jalan berbasis IoT dan Android. Aksi ini dapat dilakukan setelah petugas memilih fitur waktu awal atau waktu waktu akhir pada interface otomatis.

\subsection{Pengujian Sistem}

Tahap ini merupakan tahapan untuk mengeksekusikan keseluruhan sistem baik itu perangkat keras dan perangkat lunak. Tahapan ini akan dibagi menjadi dua tahap yaitu pengujian pada perangkat keras dan perangkat lunak system monitoring dan controlling penerangan lampu jalan berbasis loT dan android.

\subsubsection{Pengujian Perangkat Keras}

Pengujian dilakukan terhadap perangkat keras dan perangkat lunak dengan metode black box, yaitu pengujian yang dilakukan berdasarkan masing-masing fungsional dari peragkat keras.

1. Hasil Pengujian Modul Relay

Pengujian modul Relay dilakukan untuk mengetahui kinerja dari modul Relay, apakah sudah berfungsi dengan baik dalam menyalakan dan mematikan lampu. Pengujian pada modul Relay dapat dilihat pada

TABEL I. HASIL PENGUJIAN MOdUl Relay

\begin{tabular}{|c|c|c|c|c|}
\hline $\begin{array}{c}\text { Nama } \\
\text { Modul }\end{array}$ & Setting & Input & Output & $\begin{array}{c}\text { Kondisi } \\
\text { Lampu }\end{array}$ \\
\hline \multirow{3}{*}{ Relay } & \multirow{2}{*}{ Manual } & Low & On & Menyala \\
\cline { 3 - 5 } & & High & Off & Mati \\
\cline { 2 - 5 } & \multirow{2}{*}{ Otomatis } & Low & On & Menyala \\
\cline { 3 - 5 } & & High & Off & Mati \\
\hline
\end{tabular}

Tabel 1 menunjukkan hasil dari penggunaan Relay pada perangkat keras, Relay dipasang pada Normali Open sehingga bekerja pada aktif Low. Jika Relay di-set low maka kondisi dari Relay akan "ON" dan lampu akan menyala, begitu juga sebaliknya jika di-set high maka Relay akan "OFF" dan lampu akan mati. 


\section{Pengujian Sensor LDR (Ligh Dependent Resistor)}

Proses pengujian sensor LDR ini dilakukan untuk mengukur tingkat intensitas cahaya (lux) yang dapat dibaca oleh sensor. Terdapat tiga buah sensor yang terpasang pada masing-masing lampu dengan menggunakan ADS1115.

\section{- Pengujin Sensor LDR ke 1}

TABEL II. HASIL PenguJIAN SENSOR LDR1

\begin{tabular}{|c|c|c|c|c|c|}
\hline \multirow[b]{2}{*}{ No } & \multirow[b]{2}{*}{ Waktu } & \multicolumn{2}{|c|}{ Keadaan Sensor } & \multirow[b]{2}{*}{ Satuan } & \multirow[b]{2}{*}{ Keterangan } \\
\hline & & Normal & $\begin{array}{c}\text { Lampu } \\
\text { nyala }\end{array}$ & & \\
\hline 1 & 10 detik & 234 & 1197 & ohm & $\begin{array}{l}\text { Di dalam } \\
\text { ruangan }\end{array}$ \\
\hline 2 & 10 detik & 230 & 1201 & ohm & $\begin{array}{l}\text { Di dalam } \\
\text { ruangan }\end{array}$ \\
\hline 3 & 10 detik & 235 & 1192 & ohm & $\begin{array}{l}\text { Di dalam } \\
\text { ruangan }\end{array}$ \\
\hline 5 & 10 detik & 232 & 1203 & ohm & $\begin{array}{l}\text { Di dalam } \\
\text { ruangan }\end{array}$ \\
\hline 6 & 10 detik & 233 & 1204 & ohm & $\begin{array}{l}\text { Di dalam } \\
\text { ruangan }\end{array}$ \\
\hline 7 & 10 detik & 235 & 1202 & ohm & $\begin{array}{l}\text { Di dalam } \\
\text { ruangan }\end{array}$ \\
\hline 8 & 10 detik & 230 & 1202 & ohm & $\begin{array}{l}\text { Di dalam } \\
\text { ruangan }\end{array}$ \\
\hline 9 & 10 detik & 230 & 1201 & ohm & $\begin{array}{l}\text { Di dalam } \\
\text { ruangan }\end{array}$ \\
\hline 10 & 10 detik & 232 & 1201 & ohm & $\begin{array}{l}\text { Di dalam } \\
\text { ruangan }\end{array}$ \\
\hline
\end{tabular}

Tabel 2 Berdasarkan pengujian yang telah dilakukan pada sensor 1 yaitu LDR 1 yang terpasang pada pin A0 ADS1115. Pengujian dilakukan dengan waktu 10 detik untuk mengetahui apakah sensor LDR dapat membaca intensitas cahaya dengan baik. Pada saat keadaan nomal yaitu lampu yang terpasang dalam keadaan mati yang dimana sensor LDR hanya mendapatkan intensitas cahaya disekitarnya, sensor berhasil membaca intensitas cahaya maxsimal 235 lux dan untuk minimal 230 lux. Pada saat masing-masing lampu dinyalakan LDR dapat membaca intensitas cahaya maxsimal 1204 lux dan 1197 lux untuk minimal yang dibaca.

\section{- Pengujian Sensor LDR ke 2}

TABEL III. HASIL ENGUJIAN SENSOR LDR2

\begin{tabular}{|c|c|c|c|c|c|}
\hline \multirow[b]{2}{*}{ No } & \multirow[b]{2}{*}{ Waktu } & \multicolumn{3}{|c|}{ Keadaan Sensor } & \multirow[b]{2}{*}{ Keterangan } \\
\hline & & Normal & $\begin{array}{c}\text { Lampu } \\
\text { nyala }\end{array}$ & Satuan & \\
\hline 1 & 10 detik & 583 & 1176 & ohm & $\begin{array}{l}\text { Di dalam } \\
\text { ruangan }\end{array}$ \\
\hline 2 & 10 detik & 577 & 1174 & ohm & $\begin{array}{l}\text { Di dalam } \\
\text { ruangan }\end{array}$ \\
\hline 3 & 10 detik & 584 & 1182 & ohm & $\begin{array}{l}\text { Di dalam } \\
\text { ruangan }\end{array}$ \\
\hline 5 & 10 detik & 578 & 1182 & ohm & $\begin{array}{l}\text { Di dalam } \\
\text { ruangan }\end{array}$ \\
\hline 6 & 10 detik & 578 & 1182 & ohm & $\begin{array}{l}\text { Di dalam } \\
\text { ruangan }\end{array}$ \\
\hline 7 & 10 detik & 584 & 1180 & ohm & $\begin{array}{l}\text { Di dalam } \\
\text { ruangan }\end{array}$ \\
\hline
\end{tabular}

\begin{tabular}{|c|c|c|c|c|c|}
\hline 8 & 10 detik & 576 & 1180 & ohm & $\begin{array}{l}\text { Di dalam } \\
\text { ruangan }\end{array}$ \\
\hline 9 & 10 detik & 576 & 1181 & ohm & $\begin{array}{l}\text { Di dalam } \\
\text { ruangan }\end{array}$ \\
\hline 10 & 10 detik & 579 & 1182 & ohm & $\begin{array}{l}\text { Di dalam } \\
\text { ruangan }\end{array}$ \\
\hline
\end{tabular}

Pada sensor 2 yaitu LDR 2 yang terpasang pada pin A1 ADS1115. Pengujian dilakukan dengan rentan waktu 10 detik untuk mengetahui apakah sensor LDR dapat membaca intesitas cahaya dengan baik. Pada saat keadaan nomal yaitu lampu yang terpasang dalam keadaan mati yang dimana sensor LDR hanya mendapatkan intensitas cahaya disekitarnya, sensor dapat membaca intensitas cahaya (lux) maxsimal 584 lux dan 576 lux untuk minimal yang didapatkan. Ketika masing-masing lampu dinyalakan LDR dapat membaca intensitas cahaya (lux) maxsimal 1183 lux dan 1174 lux untuk minimal yang dibaca.

- Pengujin Sensor LDR ke 3

TABEL IV. hasil Pengujian Sensor LDR3

\begin{tabular}{|c|c|c|c|c|c|}
\hline \multirow[b]{2}{*}{ No } & \multirow[b]{2}{*}{ Waktu } & \multicolumn{3}{|c|}{ Keadaan Sensor } & \multirow[b]{2}{*}{ Keterangan } \\
\hline & & Normal & $\begin{array}{c}\text { Lampu } \\
\text { nyala }\end{array}$ & Satuan & \\
\hline 1 & $\begin{array}{c}10 \\
\text { detik }\end{array}$ & 517 & 1024 & ohm & $\begin{array}{l}\text { Di dalam } \\
\text { ruangan }\end{array}$ \\
\hline 2 & $\begin{array}{c}10 \\
\text { detik }\end{array}$ & 519 & 1024 & ohm & $\begin{array}{l}\text { Di dalam } \\
\text { ruangan }\end{array}$ \\
\hline 3 & $\begin{array}{c}10 \\
\text { detik }\end{array}$ & 518 & 1024 & ohm & $\begin{array}{l}\text { Di dalam } \\
\text { ruangan }\end{array}$ \\
\hline 5 & $\begin{array}{c}10 \\
\text { detik }\end{array}$ & 519 & 1024 & ohm & $\begin{array}{l}\text { Di dalam } \\
\text { ruangan }\end{array}$ \\
\hline 6 & $\begin{array}{c}10 \\
\text { detik }\end{array}$ & 516 & 1024 & ohm & $\begin{array}{l}\text { Di dalam } \\
\text { ruangan }\end{array}$ \\
\hline 7 & $\begin{array}{c}10 \\
\text { detik }\end{array}$ & 513 & 1024 & ohm & $\begin{array}{l}\text { Di dalam } \\
\text { ruangan }\end{array}$ \\
\hline 8 & $\begin{array}{c}10 \\
\text { detik }\end{array}$ & 517 & 1024 & ohm & $\begin{array}{l}\text { Di dalam } \\
\text { ruangan }\end{array}$ \\
\hline 9 & $\begin{array}{c}10 \\
\text { detik }\end{array}$ & 521 & 1024 & ohm & $\begin{array}{l}\text { Di dalam } \\
\text { ruangan }\end{array}$ \\
\hline 10 & $\begin{array}{c}10 \\
\text { detik }\end{array}$ & 516 & 1024 & ohm & $\begin{array}{l}\text { Di dalam } \\
\text { ruangan }\end{array}$ \\
\hline
\end{tabular}

Berdasarkan pengujian yang telah dilakukan pada sensor 3 yaitu LDR 3 yang terpasang pada pin AO pada wemos D1. Pengujian dilakukan dengan rentan waktu 10 detik, hasil intensitas cahaya dari sensor ke 3 yang dapat dibaca dalam keadaan normal paling tinggi adalah 519 lux, dan paling terendah adalah 513 lux. Untuk keadaan lampu menyala hasil yang didapatkan intensitas cahaya (lux) maxsimal 1204 lux tidak bias naik lagi karena pada sensor ke 3 ini dipasang pada pin A0 wemos D1.

\subsubsection{Hasil Pengujian Perangkat Lunak}

Proses pengujian sistem monitoring dan controlling penerangan lampu jalan berbasis android ini dilakukan dengan menggunakan metode black box. Pengujian ini 
dilakukan untuk mengetahui apakah fitur-fitur yang terdapat pada sistem android ini berjalan dengan baik.

\section{Pengujian Fungsi Form Login}

Pengujian fungsi login dilakukan untuk memastikan apakah berfungsi dengan baik dan berjalan sesuai dengan diharapkan. Pengujian

TABEL V. HASIL PENGUJIAN FORM LOGIN

\begin{tabular}{|c|c|c|c|}
\hline Skenario & $\begin{array}{c}\text { Hasil yang } \\
\text { diharapka } \\
\text { n }\end{array}$ & $\begin{array}{c}\text { Hasil } \\
\text { pengujian }\end{array}$ & $\begin{array}{c}\text { keteranga } \\
n\end{array}$ \\
\hline $\begin{array}{c}\text { Formusernam } \\
\qquad e \\
\text { dan password } \\
\text { tidak diisi } \\
\text { semuannya } \\
\text { atau salah satu } \\
\text { kosong }\end{array}$ & $\begin{array}{c}\text { Proses } \\
\text { login gagal } \\
\text { dan tetap } \\
\text { berada di } \\
\text { halaman } \\
\text { login }\end{array}$ & $\begin{array}{c}\text { Sesuai } \\
\text { dengan } \\
\text { yang } \\
\text { diharapka } \\
\mathrm{n}\end{array}$ & Valid \\
\hline $\begin{array}{c}\text { Formusernam } \\
e \\
\text { dan password } \\
\text { diisi dengan } \\
\text { benar }\end{array}$ & $\begin{array}{c}\text { Proses } \\
\text { login } \\
\text { berhasil } \\
\text { dan } \\
\text { diarahkan } \\
\text { ke } \\
\text { halaman } \\
\text { menu } \\
\text { utama. }\end{array}$ & $\begin{array}{c}\text { Sesuai } \\
\text { dengan } \\
\text { yang } \\
\text { diharapka } \\
\mathrm{n}\end{array}$ & Valid \\
\hline
\end{tabular}

\section{Pengujian Fungsi Form Buat Akun}

Pengujian Formbuat atau membuat akun baru dilakukan untuk memastikan pada setiap Formnya dapat berjalan sesuai dengan diharapkan dan berjalan dengan baik. Berdasarkan pengujian yang telah dilakukan fungsi untuk membuat akun baru sudah berjalan denga baik. Berikut adalah Tabel hasil dari pengujian buat akun.

TABEL VI. hasil Pengujian halaman Buat AKun

\begin{tabular}{|c|c|c|c|}
\hline Skenario & $\begin{array}{l}\text { Hasil yang } \\
\text { diharapkan }\end{array}$ & $\begin{array}{c}\text { Hasil } \\
\text { pengujian }\end{array}$ & keterangan \\
\hline $\begin{array}{c}\text { Formbuat } \\
\text { akun } \\
\text { tidak diisi } \\
\text { semuannya } \\
\text { atau salah } \\
\text { satu } \\
\text { kosong }\end{array}$ & $\begin{array}{c}\text { Proses } \\
\text { membuat akun } \\
\text { gagal dan } \\
\text { tetap berada di } \\
\text { halaman buat } \\
\text { akun }\end{array}$ & $\begin{array}{c}\text { Sesuai } \\
\text { dengan } \\
\text { yang } \\
\text { diharapkan }\end{array}$ & Valid \\
\hline $\begin{array}{c}\text { Formbuat } \\
\text { akun } \\
\text { diisi } \\
\text { semuannya }\end{array}$ & $\begin{array}{c}\text { Proses } \\
\text { membuat akun } \\
\text { berhasil dan } \\
\text { datapemilik } \\
\text { sudah } \\
\text { disimpan pada } \\
\text { database } \\
\text { (Firebase) }\end{array}$ & $\begin{array}{c}\text { Sesuai } \\
\text { dengan } \\
\text { yang } \\
\text { diharapkan }\end{array}$ & Valid \\
\hline
\end{tabular}

\section{Pengujian Fungsi Kontrol Lampu Jalan}

Pengujian pada sisi fungsi kontrol lampu dilakukan untuk memastikan apakah sudah berhasil dengan baik. Fungsi kontrol dikategorikan menjadi dua agian yaitu mengontrol dengan cara manual dan otomatis.

a. Menyalakan Secara Manual

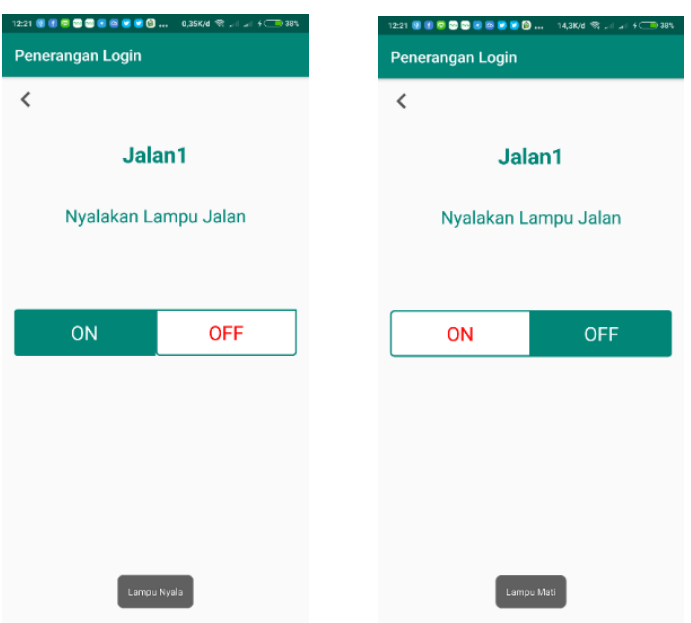

Gambar 24. Hasil Pengujian Kontrol Lampu Manual

Pada Gambar 24 adalah hasil dari sistem monitoring dan controlling penerangan lampu jalan berbasis IoT dan android yang didapatkan pada saat menyalakan dan mematikan lampu jalan. Jika petugas memilih fitur" ON" pada sistem manual maka lampu akan menyala dan fitur pada "OFF" akan mati (berwarna merah), begitu juga dengan sebaliknya jika petugas memilih fitur "OFF" maka lampu akan mati.

\section{b. Menyalakan Secara Otomatis}

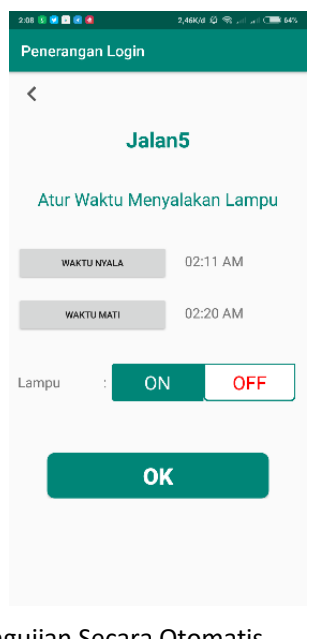

Gambar 25. Hasil Pengujian Secara Otomatis

Pada Gambar 25 dilakukan pengujian secara otomatis yaitu dengan penggunaan penjadwalan timer. 
penjadwalan dlakukan dengan meng-input-kan dua kondisi yaitu waktu menyala dan waktu mati, untuk waktu input-an waktu menyala adalah 02.11 AM untuk waktu matinya adalah 02.20 AM. Hasil yang dilakukan dalam pengujian berhasil, pada rentan waktu 02.11 AM s/d 02.20 AM lampu jalan yang sebelumnya "OFF" dapat menyala selama rentan waktu di input-kan.

\section{c. Monitoring Lampu Jalan}

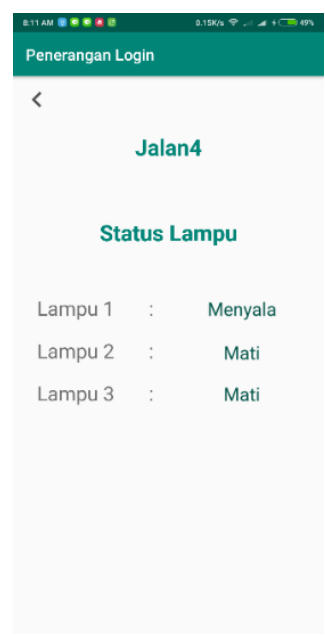

Gambar 26. Hasil Pengujian Monitoring Lampu

Gambar 26 merupakan tampilan untuk memonitoring keadaan lampu dari segi menyala atau mati, pengujian berhasil dilakukan saat sensor LDR mendeteksi intensitas cahaya dari lampu kurang dari 960 lux maka lampu dikatakan mati dan sebaliknya jika lebih maka lampu diangap menyala.

\section{Kesimpulan dan Saran}

\subsection{Kesimpulan}

Berdasarkan penelitian dan hasil pengujian yang telah dilakukan, maka diperoleh beberapa kesimpulan sebagai berikut:

1. Sistem berbasis android melakukan 3 aksi utama yaitu menyalakan, mematikan lampu secara manual dan otomatis serta dapat me-monitoring keadaan lampu. Berdasarkan skenario pengujian, sistem telah dapat melakukan ke tiga aksi utama sistem yaitu menyalakan dan mematikan lampu secara manual dan otomatis, serta sistem berbasis android ini sudah dapat memonitoring keadaan lampu menyala atau mati.

2. Controlling lampu dapat dilakukan dengan 2 cara yaitu secara manual dan otomatis. Digunakan modul relay dalam memakukan controlling lampu. Relay dipasang pada normali open, jika relay di input-kan low maka lampu menyala dan jika relay di-input-kan high maka lampu mati.

3. Setiap sensor LDR memiliki tingkat ketelitian yang berbeda-beda sesuai dengan jarak sensor dan lampu sehingga perlu dilakukan kalibrasi pada sistem. Sensor LDR1 mendapatkan nilai minimal lux pada saat lampu mati adalah 230 (lux) dan pada saat lampu menyala mendapatkan nilai maksimal 1204 (lux), LDR2 mendapatkan nilai minimal lux pada saat lampu mati adalah 576 (lux) dan pada saat lampu menyala mendapatkan nilai maksimal 1182 (lux) dan LDR3 mendapatkan nilai minimal lux pada saat lampu mati adalah 513 (lux) dan pada saat lampu menyala mendapatkan nilai maksimal 1024 (lux).

4. Sensor LDR jika mendapatkan intensitas cahaya lebih dari 966 (lux) maka akan mendeteksi bahwa lampu menyala, begitu juga dengan sebaliknya jika medeksi kurang dari 966 (lux) maka lampu dinyatakan mati dan dapat dilihat pada fitur monitoring lampu di android.

\subsection{Saran}

Diharapkan jika penelitian ini dilanjutkan untuk kedepannya, agar dapat dipertimbangkan saran berikut ini:

1. Diharapkan sistem yang dibangun dapat dikembangkan lebih lanjut dengan menambahkan sensor terutama sensor kendaraan untuk mendeteksi jenis kendaraan yang melintasi jalan tersebut.

2. Diharapkan agar dapat mendeteksi posisi masingmasing lampu yang mengalami gangguan seperti ganguan arus listrik yang mati dan mati secara tibatiba.

3. Diharapkan untuk kedepannya sistem yang dibuat untuk memonitoring dan controlling penerangan lampu agar lebih kompleks lagi.

\section{UCAPAN TERIMA KASIH}

Terima kasih saya ucapkan kepada seluruh yang telibat dalam penelitian ini baik itu dosen pembimbing yang telah membimbing dalam penelitian ini sampai selesai dan teman-teman dari angkatan 2015 yang telah membatu dan konstribusi dalam penelitian ini baik berupa material ataupun materi.

\section{Daftar PUstaka}

[1] I. G. A. Putra, A. A. N. Amrita, and I. M. A. Suyadnya, "Rancang Bangun Alat Monitoring Kerusakan Lampu Penerangan Jalan Umum Berbasis Mikrokontroler dengan Notifikasi SMS," J. Comput. Sci. Informatics Eng., vol. 2, pp. 90-99, 2018, doi: 10.29303/jcosine.v2i2.141.

[2] H. Amri, J. Lianda, and J. Custer, "Sistem Pengaturan Energi Penerangan Jalan Umum Berbasis Arduino Uno," Pros. Semin. Nas. Fis. Univ. Riau, no. 3, pp. 3135, 2018.

[3] S. Buwana, Dewangga P. S. "Perancangan Controlling and Monitoring Penerangan Jalan Umum (PJU) Energi Panel Surya Berbasis Fuzzy Logic Dan Jaringan 
Internet," Pros. Semin. Nas. ReTII, vol. 0, no. 0, pp. 186-192, 2017.

[4] D. U. Suwarno and A. Herpurnomo, "Controlling and Detection of Public Street Light Using Wireless Connection," Conf. Senat. STT Adisutjipto Yogyakarta, vol. 4, 2018, doi: 10.28989/senatik.v4i0.247.

[5] E. I. Dawud, "Sistem Monitoring Lampu Penerangan Jalan Umum Menggunakan Mikrokontroler Arduino Dan Sensor Ldr Dengan Notifikasi Sms," J. Tek. Elektro, Univ. Mercu Buana, vol. 7, no. 2, pp. 101105, 2016.

[6] M. K. Imam, G. Abdillah, and R. Yuniarti, "Pembuatan Sistem Pengontrol Intensitas Cahaya Lampu Menggunakan Raspberry Pi Berbasis Mobile," pp. 302-306, 2018.

[7] T. U. Syamsuri, "Kontrol Lampu Jalan Untuk Menghemat Energi," vol. 7, pp. 28-33, 2015.

[8] N. F. Azzahra, "Rancang Bangun Purwarupa lot ( Internet Of Things ) Kendali Lampu Dengan Protokol Mqtt pada Studi Kasus Skala Rumah Tangga," J. Ilm., vol. 3, no. 1, pp. 1-4, 2018.

[9] Y. Widya and A. Rustam, "Perancangan Aplikasi Mobile Untuk Pemasaran Produk Dan Jasa Ke Berbagai Situs E-Commerce Di Indonesia," vol. VI, no.
2, pp. 88-99, 2017.

[10] R. Margaretha, "Pengendali Lampu Rumah Menggunakan Aplikasi HP Android Melalui Komunikasi Bluetooth Berbasis Mikrokontroler Atmega 328," Universitas Sumatera Utara, 2018.

[11] N. P. Dewandra, "Wireless Smart Tag Device Sebagai Sistem Keamanan Rumah Sistem Keamanan Rumah," Universitas Islam Indonesia, 2018.

[12] M. D. Putro, "Sistem Pengaturan Pencahayaan Ruangan Berbasis Android pada Rumah Pintar," vol. 5, no. 3, 2016.

[13] A. K. Tsauqi et al., "Saklar Otomatis Berbasis Light Dependent Resistor (Ldr) Pada Mikrokontroler Arduino Uno," vol. V, pp. 19-24, 2016.

[14] J. Yos, S. Pabean, and D. Probolinggo, "Perancangan dan Pembuatan Sistem Penyalaan Lampu Otomatis Dalam Ruangan Berbasis Arduino Menggunakan Sensor Gerak dan Sensor Cahaya," J. Penelit., vol. 10, no. 1, pp. 9-16, 2014.

[15] Y. Alif, K. Utama, S. St, I. Tamaji, and R. H. Sanjaya, "Desain dan Pengendalian Warna Mood Lamp Otomatis Berdasarkan Waktu Menggunakan Aplikasi Android Pada Smartphone," vol. 2, no. 2, 2018. 